Literature for an Age of Science

By Prof. Hyman Levy and Helen Spalding. Pp. $x+250$. (London: Methuen and Co., Ltd., 1952.) 15s. net.

THIS book is a joint venture by two people whose disciplines lie respectively in the fields of science and literature. At the outset, it can be said that their work is both timely and important. It extends into a larger sphere, and away from the detailed mechanism of criticism-the rational treatment of literature such as was suggested by I. Richards in his "Principles of Literary Criticism".

Prof. H. Levy and Helen Spalding attempt to see literature as a feature of social life and to judge its importance and its potentialities within this life. The functions of poetry, drama and the novel are reviewed in relation to modern sociological ideas. Science and the arts are aspects of one venture ; they should be complementary and mutually supporting. But at present we are far from realizing this ideal : a scientist or a technologist can express the quality of truth in his work and can thrive, whereas a writer who expresses an important but unpalatable truth cannot expect encouragement. Truth in science can be commercially useful, but truth in literature cannot always be. Commerce is not concerned with the whole of truth, and yet human beings are. Science, with the material rewards and the intellectual satisfactions heavily weighted in its favour, tends to attract to itself the intellectual vitality of society to the relative impoverishment of the arts.

There are few inducements to help equalize the flow of creative energy in all directions, for the pressures that are responsible for the actual distribution of this energy are in no way consciously controlled or directed but are left to the random play of social forces only dimly apprehended. Even the academio rewards given for creative work in science are not given for creative work in literature, though the desiccated dissection (not even worthy of printing), of a minor poet, may bring its producer a Ph.D.

Nevertheless, this near-Marxist view of literature presented by the authors will be considered partial, if not perverse, by most readers. It is notoriously lacking in human individual qualities, it knows nothing of ultimate values and it tends to be unimaginative, arid and unentertaining.

$$
\text { W. L. SUMNER }
$$

Practical Organic Chemistry

By Dr. Frederick George Mann and Dr. Bernard Charles Saunders. Third edition. Pp. xv +466 . (London, New York and Toronto : Longmans, Green and Co., Ltd., 1952.) 18s. net.

IN the third edition of this popular manual, the authors have made a thorough revision of the text, based on sixteen years of experience of its use in the laboratory, and have somewhat raised the general standard by an increase in the range of the preparations and an extension of the section dealing with identifications, greater emphasis now being placed on the preparation of crystalline derivatives. A new short section, which should prove particularly useful in view of the increased cost of chemicals, describes the use of apparatus for small-scale manipulations. The macro methods of estimation of carbon, hydrogen and nitrogen have at last disappeared, and have been replaced by a section on semi-micro methods of analysis.

Descriptions of methods of manipulation and experimental directions throughout are extremely clear and precise, and the theoretical notes preceding each experiment should enable the student to understand the general principles involved. The scope of the book is perhaps still too limited to justify the authors' claim that it should now cater fully for the needs of students working for honours degrees; it certainly meets admirably the requirements of passdegree students, and the price, although about double that of the second edition, is still very moderate by ourrent standards.

C. BUdhanaN

Hobhouse Memorial Lectures, 1941-50

Pp. vii + 268. (London: Oxford University Press, 1952.) 17s. 6d. net.

THIS collection of lectures by distinguished social scientists and philosophers shows that, though Hobhouse's system of thought and belief has been severely shaken in the troubled years that have succeeded his death, efforts are still being made to follow many of the lines he laid down. C. P. Scott, an intimate colleague and friend, wrote that "his deepest instinctive belief and hope were in human progress", and that his life and work represented "an imposing expression of intellectual power allied to an almost childlike friendliness". All these things have since come under criticism, and it will be resssuring to many to find evidence in the Memorial Lectures that the kinds of intellectual courage and optimism for which Hobhouse is remembered are not yet extinguished.

The most impressive of the lectures, which shows the deepest knowledge of Hobhouse's work, and makes an attempt to translate his ideas into the mould of present-day thinking, is by Prof. H. L. Beales, who defends the constructive liberalism with whioh Hobhouse was associated from the attacks of critics of 'planning'. Hobhouse himself would also have been greatly interested by Dr. C. E. Raven's reexamination of the relationships between religion and science, which, as he points out, was very relevant to Hobhouse's central interests and is of supreme importance at the present time. Many issues which would have excited Hobhouse's mind are, moreover, touched on by Prof. Gordon Childe in his lecture on "Social Worlds of Knowledge".

\section{Beautifying India}

By M. S. Randhawa. Pp. xviii $+224+23$ plates. (Delhi and Bombay: Rajkamal Publications, I.td., 1950.) 15 rupees ; $28 s$.

7 HIS is virtually a miscellany on art, science and resthetics in which the author is concerned with the problem of beautifying his native land--this to coincide with what he hopes and believes to be the inception of a period of prosperity. While one may not agree with all the author's views and opinions, one cannot fail to appreciate his enthusiasm, the lucid exposition of his views, and his evident sincerity. Like other tropical regions, India needs beautifying. In the author's view, this will only come about by a general awakening of interest and a conscious effort to bring to bear the right kind of action-that is, a conscious planning of the flora and fauna with the object of creating a pleasing pattern of colour throughout the land. Bio-æesthetic planning is essentially planned ecology, and, in its application to the Indian scene, would take the form of a widespread planting and appropriate massing of ornamental flowering trees. On this subject, the author has brought together much useful information which may well have a wider application to tropical regions in general. 